\title{
Modelling Torrential Rain Flows in Urban Territories: Floods - Natural Channels (The Case Study of Madeira Island)
}

\author{
Sérgio Lousada ${ }^{1,4,5,6,7}$, Luís Loures ${ }^{2,3,4}$ \\ ${ }^{1}$ Faculty of Exact Sciences and Engineering (FCEE), Department of Civil Engineering and Geology (DECG), University of Madeira (UMa), \\ Funchal, Portugal \\ ${ }^{2}$ Polytechnic Institute of Portalegre (IPP), Portalegre, Portugal \\ ${ }^{3}$ Research Centre for Tourism, Sustainability and Well-being (CinTurs), University of Algarve, Faro, Portugal \\ ${ }^{4}$ VALORIZA - Research Centre for Endogenous Resource Valorization, Portalegre, Portugal \\ ${ }^{5}$ Environmental Resources Analysis Research Group (ARAM), University of Extremadura, Badajoz, Spain \\ ${ }^{6}$ Institute of Research on Territorial Governance and Inter-Organizational Cooperation, Dąbrowa Górnicza, Poland \\ ${ }^{7}$ CITUR - Madeira - Centre for Tourism Research, Development and Innovation, Madeira, Portugal
}

Email address:

slousada@staff.uma.pt (S. Lousada), Icloures@ipportalegre.pt (L. Loures)

\section{To cite this article:}

Sérgio Lousada, Luís Loures. Modelling Torrential Rain Flows in Urban Territories: Floods - Natural Channels (The Case Study of Madeira Island). American Journal of Water Science and Engineering. Vol. 6, No. 1, 2020, pp. 17-30. doi: 10.11648/j.ajwse.20200601.13

Received: October 9, 2019; Accepted: January 10, 2020; Published: February 4, 2020

\begin{abstract}
The understanding of flood phenomena regarding torrential rain, occurring in natural channels within urban areas represents a crucial aspect to increase safety and life's standards of the populations, issues that are deeply related to a welldeveloped sustainable urban and spatial planning. In this regard, flows inside urban areas have great heterogeneity, therefore their characterization requires a formulation which explicitly incorporates this spatial variability. The present study intends to establish a parallel between the selected models, numerical and reduced, enabling to examine their contributions regarding the flow characterization and water height in natural channels within urban settlements located near the river mouth and inserted in hydrographic basins with accentuated orography, as is the case of Funchal urban area at Madeira Island. Based on the available resources, the geometric simplicity of the study case and the results, the most appropriate method is the programmed spreadsheet, providing prompt and reliable information for the design of better adapted hydraulic structures that can face this extreme phenomenon, checking the adaptability of existing structures, as well as in the decision-making process concerning urban planning, safeguarding the populations in similar conditions.
\end{abstract}

Keywords: Floods, Modelling, Natural Channels, Sustainable Spatial Planning, Urban Agglomerations

\section{Introduction}

Floods occur when the water of watercourses or stormwater drainage systems overspill the drain sections and consequently occupy urban areas - i.e. streets, sidewalks, commercial areas, industrial areas, homes $[1,2]$. The effects associated with this typology of event depends on geographical and climatic features of watersheds, as well as on anthropogenic factors - i.e. the occupation of the basin soil and the urbanization degree of potential flood zones, as it happens in Mexico [3], Poland [4], Spain [5]; Greece [6], Sudan [7], Italy [8] or Norway [9].

Thus, the occurrence of intense rainfalls translates into severe floods in regions that are more exposed to this typology of phenomena, as is the case of the Madeira Island [10-12]. According to the analysis of climate change models undertaken so far, an increase in the frequency and intensity of these occurrences is expected, announcing future hardship and unsafety to urban agglomerations [13-15]. Also, the planned modifications of precipitation will have impacts on urban water cycles - i.e. the amount of water, intercepted or undercover courses, or even drained - leading to the necessity to incorporate this issues, with a stronger commitment attitude by the main-actors and politicians, in the processes of urban planning - especially regarding the design and management of drainage systems, and the 
management of waters in urban areas [16-18]. Unfortunately, the above-mentioned uncertainties about the impact of those changes in precipitation are expected to continue in a longterm $[19,20]$.

In this regard, the considerable concentration of buildings, roads, and population in the surrounding areas of water courses lead to successive amendments of the original bedrock - i.e. transverse and lengthwise - which consequently will intensify the arising from a spontaneous flood - a recurring issue in Madeira Island [10, 21-24]. These flood events are originated in intense rainfall compressed in a short period of time, leading to the creation of a drastically variation on the flows, which mainly causes the obstruction of the channel by entrainment of debris - i.e. flash floods, or landslides - or in abundant rainfall over several days or weeks - i.e. full sluggish or progressive [25-30].

Here, can be exposed the dramatic case occurred on 20 February 2010, at Madeira Island, where after a long rainy season allied to an adverse weather situation has caused a massive alluvium that has reached strongly several urban areas at the South of the Island - particularly on the municipalities of Funchal and Ribeira Brava. Such disaster has made dozens of fatalities and missing persons, as well as high destruction of infrastructure and equipment [24, 31-33]. According to several authors, [34-40], that have previously studied this type of phenomena throughout time - worldwide and in different contexts - the exposed prevention and management measures are still in a grey zone and presents considerable differences from region to region.

Such events demonstrate the urgency to know in depth the behaviour of surface water in urban areas [41] and their interaction with the drainage systems, as well as the need to correctly characterize the flow in natural channels [42] - i.e. through hydrodynamic simulation models, enabling to create enhanced tools to aid in the prevention and management of floods [43, 44].

In fact, an increase of literature related to modelling [4547], floods [36, 20, 48-50], land management [10, 22, 51-53], and related parameters [54-67] has been produced throughout the last two decades, which benefits the elaboration of further and improved studies regarding the previously stated aspects. Still, further studies need to be developed aiming to fully understand the thematic from all the perspectives.

The present study intends to evaluate the contributions and adequacy of the selected models - programmed spreadsheet, HEC-RAS program and experimental model - regarding floods due to torrential rain in natural channels within urban settlements located near the river mouth and inserted in hydrographic basins with accentuated orography, applied to Funchal urban area at Madeira Island, based on parameters regarding the flow characterization ( $\mathrm{Fr}, \mathrm{Re}$ and $\mathrm{n}$ ) and water height $(\mathrm{h})$.

\section{Methodology}

A quantitative methodology was considered, a nomothetic one - methodology that deals with the establishment of general laws or the study of recurring phenomena, especially with natural events - once it promotes the development of research along with established protocols and specific techniques $[46,68,69]$. Thus, a case study method approach $[17,70-73]$ has been used. In the following, a scheme synthesizing the methodological approach is presented (Figure 1).

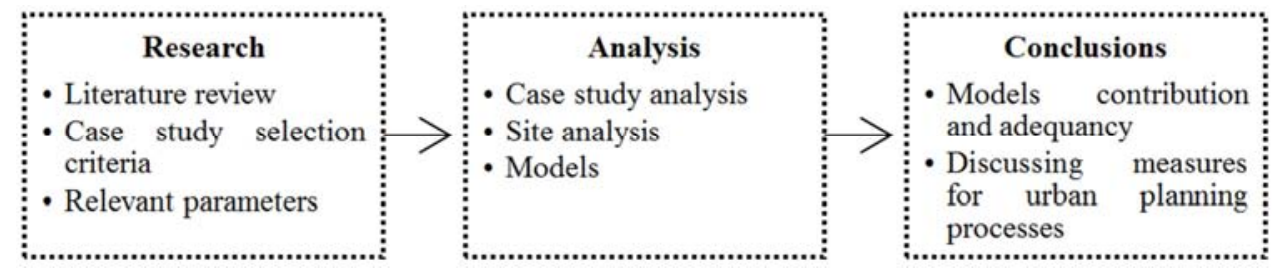

Figure 1. Methodological approach scheme.

\subsection{Study Area}

The Madeira Archipelago is located in the North Atlantic Ocean, between latitude $30^{\circ} 01^{\prime} \mathrm{N}$ and $33^{\circ} 08^{\prime} \mathrm{N}$ and between longitude $15^{\circ} 41^{\prime} \mathrm{W}$ and $17^{\circ} 16^{\prime} \mathrm{W}$. Covering an area of $802 \mathrm{~km}^{2}$, the Madeira Archipelago is composed of the following islands: Madeira $\left(742 \mathrm{~km}^{2}\right)$ (Figure 2), Porto Santo $\left(43 \mathrm{~km}^{2}\right)$ (Figure 2), Desertas $\left(14 \mathrm{~km}^{2}\right)$, and Selvagens (3 $\mathrm{km}^{2}$ ). At Table 1, it is presented a summary of the main physical features of Madeira Island [74-78].

Table 1. Physical features of Madeira island (adapted from França \& Almeida, 2003).

\begin{tabular}{ll}
\hline Physical features & \\
Average altitude & $646 \mathrm{~m}$ \\
Highest peak & Pico Ruivo $(1862 \mathrm{~m})$ \\
Average slope & $56 \%$ \\
Perimeter & $177.3 \mathrm{~km}$ \\
Area & $742 \mathrm{~km}^{2}$ \\
Predominant soils & Andosols $(42 \%)$ \\
Average daily temperature: & \\
Maximum (August) & $23^{\circ} \mathrm{C}$ \\
Minimal (February) & $5.4^{\circ} \mathrm{C}$ \\
\hline
\end{tabular}




\begin{tabular}{ll}
\hline Prevailing winds: & N-NE \\
Direction & $30 \mathrm{~km} / \mathrm{h}(\mathrm{S}-\mathrm{SW})$ \\
Maximum average velocity (and direction) & $1628 \mathrm{~mm}$ \\
Weighted average annual precipitation & \\
\hline
\end{tabular}

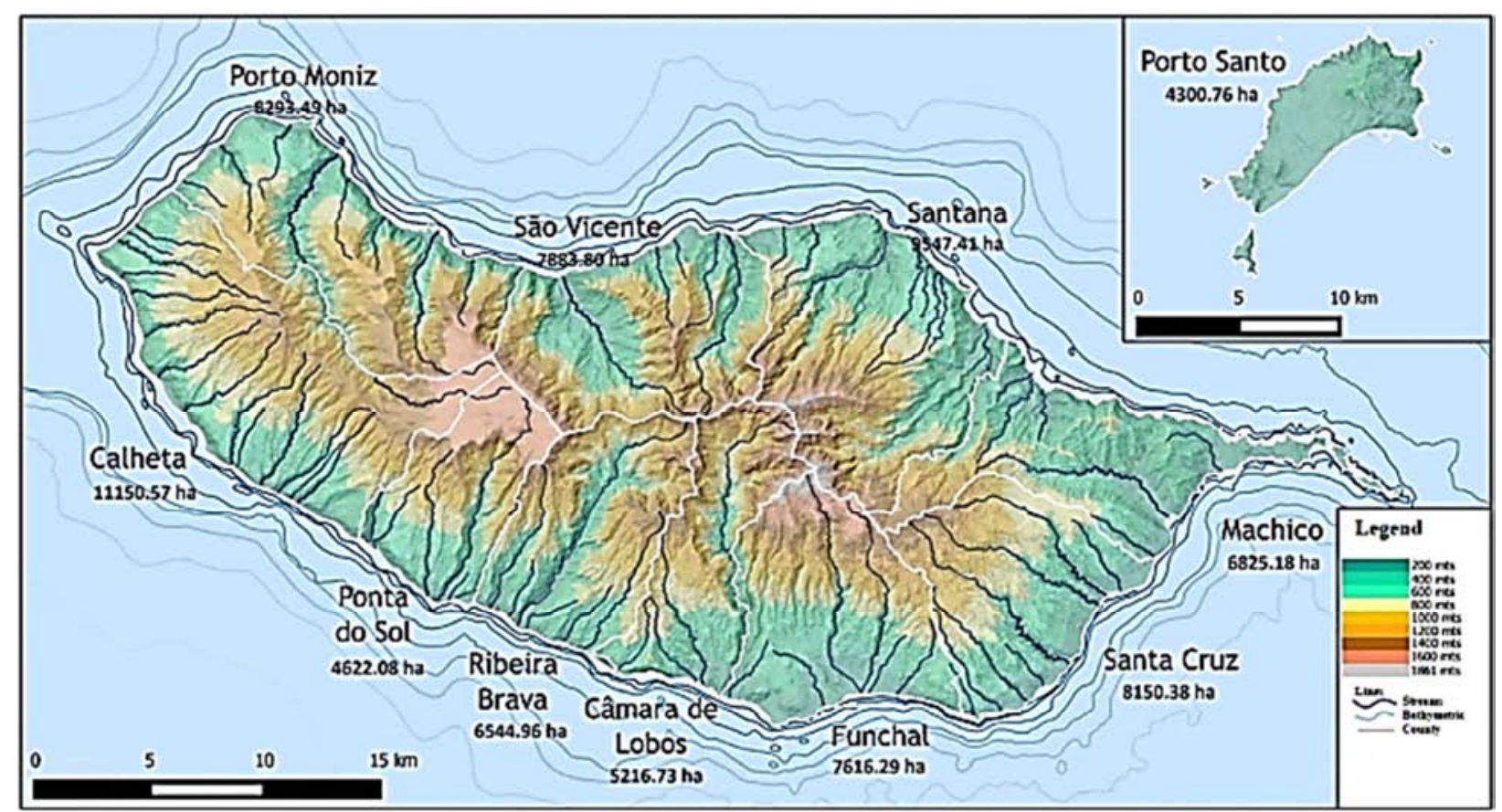

Figure 2. Madeira Island relief chart (source: Wikimedia Commons).

The Archipelago presents singular conditions that contribute to the occurrence of potentially dangerous floods $[79,24]$. Among these critical conditions could be highlighted that: in the archipelago exists more than 120 watersheds occupying almost the entire territory $\left(741 \mathrm{~km}^{2}\right)$, being that, approximately, 95\% have an area smaller than 25 $\mathrm{km}^{2}$; the 7 biggest basins (with exception to basins of Funchal) corresponds to $40 \%$ of the total Island surface - if the Funchal's basins are considered, the percentage rises to $45 \%$ (10 basins); riversides have, in general, short lengths (below $21 \mathrm{~km}$ ) and the time of concentration is relatively low (less than 2 hours) in comparison with the correspondent watersheds; rugged terrain promotes vertical impulsion of maritime tropical air masses coming from the southwest; free surface flow's fast convergence into the river channels and the high drainage density levels; deeply changed volcanic geological substrate and consequently less permeable; embedded v-shaped valleys, enabling greater interaction between landslides and river dynamics [80, 77, 81, 78].

Also, intense short duration precipitation is the factor that triggers the most dangerous floods, caused by the conjunction of several factors such as: the weakening of the Azores anticyclone during the Winter; increasing passage of low-pressure centers with frontal systems associated; increased meridian circulation and invasions of cold air at high altitude - leading to the creation of low-pressure valleys and their respective stationary depressions, the so-called cold air drops; stronger convective activity; the large thermal gradient between the low and middle troposphere $[80,82,83$,
78].

Considering the several events of flood - disastrous for urban agglomerations located at the river's mouth and its surrounding areas - the selection of Funchal and its three watersheds with their main streams as cases study (Figure 3) to develop such study is seen as appropriate since it presents a lot of factors that contribute to torrential rain flows in urban agglomerations, such as: natural channels; densely populated areas - occupied by buildings, from housing to services and commerce; flood background [24]; and also issues related to urban planning and land management processes [10] conditioning the design of the channels - in fact, some infrastructures are located upstream occupying the riverbed and banks, constricting it in width, and before 20 February 2010, where the lack of maintenance in the riverbed have influenced the height available for the flow, which has increased the likelihood of flood [80].

Geographical Information Systems (GIS) tools - i.e. ArcMap software (from ESRI company) - has been used for the characterization of watersheds and streamlined acquisition of parameters, since it has a wide range of tools in the areas of hydrology and data edition. From the Digital Terrain Model (DTM) files in ".asc" format, geographic information, provided by the Regional Direction of Spatial Planning and Environment (DROTA), has been organized and processed from ArcGIS software, complemented with Excel and AutoCAD, obtaining the required parameters that enabled the characterization of watersheds of São João, Santa Luzia and João Gomes (Table 2). 
Table 2. Summary of the watershed's characteristics.

\begin{tabular}{|c|c|c|c|}
\hline Parameter & São João & Santa Luzia & João Gomes \\
\hline \multicolumn{4}{|l|}{ Summary of the watershed's characteristics } \\
\hline Area $\left(\mathrm{km}^{2}\right)$ & 14.957 & 14.315 & 12.684 \\
\hline Perimeter $(\mathrm{km})$ & 32.920 & 31.220 & 31.400 \\
\hline Gravelius compactness coefficient & 2.400 & 2.327 & 2.486 \\
\hline Elongation factor & 16.064 & 14.955 & 17.375 \\
\hline Form factor & 0.156 & 0.144 & 0.171 \\
\hline Average altitude (m) & 733.800 & 830.100 & 852.567 \\
\hline Main watercourse length $(\mathrm{km})$ & 12.012 & 11.789 & 11.340 \\
\hline Maximum altitude of the main watercourse (m) & 1763.041 & 1787.000 & 1595.000 \\
\hline Average slope of the main watercourse & 140.500 & 144.600 & 139.600 \\
\hline Equivalent height of the main watercourse (m) & 1283.800 & 1260.500 & 1410.300 \\
\hline Equivalent slope of the main watercourse & 0.116 & 0.111 & 0.128 \\
\hline Slope $10-85$ & 0.142 & 0.151 & 0.160 \\
\hline Relief index & 0.180 & 0.179 & 0.186 \\
\hline Watershed average slope (degrees) & 25.313 & 28.038 & 24.966 \\
\hline Network form ordered by Strahler method & Order 5 & Order 5 & Order 5 \\
\hline Number of watercourses & 221.000 & 258.000 & 188.000 \\
\hline Total length of watercourses $(\mathrm{km})$ & 43.510 & 40.300 & 34.700 \\
\hline Network form ordered by Shreve method & 221.000 & 258.000 & 188.000 \\
\hline Average bifurcation ratio & 3.801 & 3.990 & 3.810 \\
\hline \multicolumn{4}{|l|}{ Time of concentration (hours) } \\
\hline Témez & 0.940 & 0.899 & 0.907 \\
\hline Ven Te Chow & 0.873 & 0.866 & 0.855 \\
\hline Giandotti & 1.545 & 1.424 & 1.338 \\
\hline Average time of concentration & 1.127 & 1.063 & 1.033 \\
\hline Watershed response time (hours) & 2.908 & 2.815 & 2.736 \\
\hline Drainage density $\left(\mathrm{km} / \mathrm{km}^{2}\right)$ & 0.086 & 0.088 & 0.091 \\
\hline Average route on the ground $(\mathrm{km})$ & 0.940 & 0.899 & 0.907 \\
\hline Sinuosity & 1.233 & 1.220 & 1.324 \\
\hline Network density (number of watercourses $/ \mathrm{km}^{2}$ ) & 14.776 & 18.023 & 14.822 \\
\hline Directrix $(\mathrm{m})$ & 9656.248 & 9557.692 & 8435.858 \\
\hline
\end{tabular}

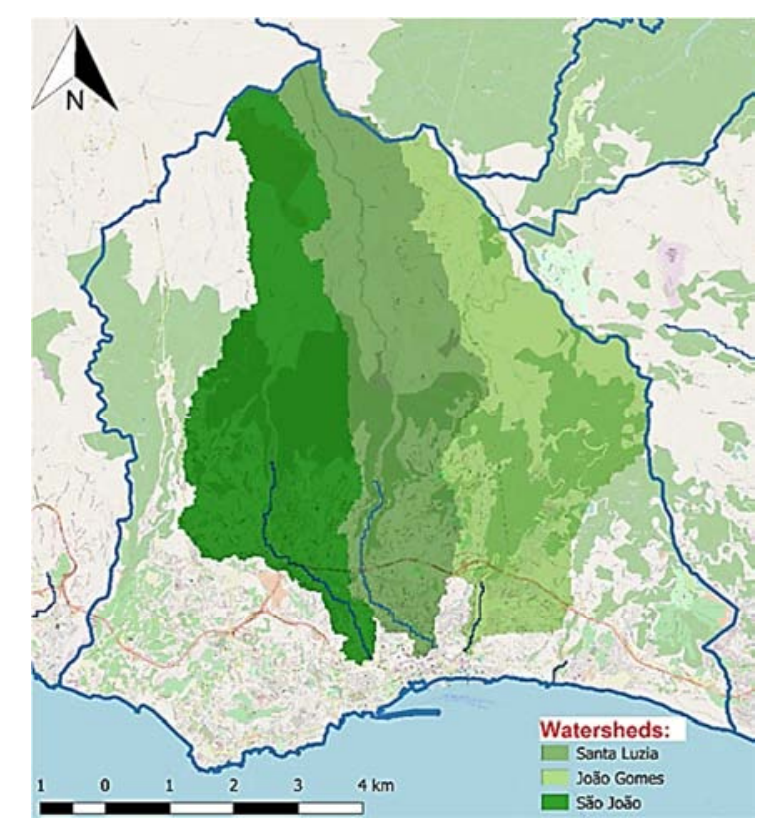

Figure 3. Location of Funchal watersheds with their main streams.

Based on the studies put forward by [76, 77], from a geological perspective, Funchal is constituted essentially by superior, intermediate complex and sedimentary cover on the river mouth: superior complex - local lava spills with tephra, between a million and six thousand years, extrusive igneous rocks; intermediate complex - lava sequences with tephra, separated by erosion levels, age between 1 and 2.5 million years, extrusive igneous rocks; sedimentary cover - riverine and marine sedimentary-gravels, mudslides, beach sands, and sedimentary rocks $[74,75,78]$.

Also, from a geographic point of view, the study area is mainly urban. Regarding the vegetal sphere, the vegetation is composed of ground cover plants found, mainly, in urban green spaces and on the banks and bottom of riversides presence of flexible vegetation, except for the areas where the bottom is covered by concrete.

\subsection{Methods and Concepts - Relevant Parameters and Formulas}

Relevant parameters, such as: time of concentration; peak flow rates; velocity; Froude and Reynolds numbers; and Manning's coefficient; are subject to punctual revisions throughout time about their formula, theoretical foundation, and application. In this sense, it will present the following parameters considering this improvement dynamic. 


\section{Time of concentration}

Table 3. Formulas to calculate the time of concentration (adapted from Lousada \& Camacho, 2018).

\begin{tabular}{ll}
\hline Formula & \\
\hline Témez & $t_{c}=0.3 \times\left(L / i^{0.25}\right)^{0.76}$ \\
Ven Te Chow & $t_{c}=0.8773 \times(L / \sqrt{i})^{0.64}$ \\
Giandotti & $t_{c}=[(4 \times \sqrt{A})+(1.5 \times L)] /(0.8 \times \sqrt{\bar{H}})$ \\
Average & $\bar{t}_{c}=\left(\sum t_{c, i}\right) / n$ \\
\hline
\end{tabular}

(i) - inclination of the main water course average; (L) - length of main water course (only Témez) or largest water course to a given point $(\mathrm{km})$; (A) basin area to a given point $\left(\mathrm{km}^{2}\right) ;(\bar{H})$ - average height of the basin, measured from the section dimension (m); (n) - number of formulas used.

The time of concentration of a basin (tc) is the time required for all the area contribute to the runoff in the output. Still, it can also be defined as the time required for a drop of water lying on the hydraulically farthest point of the basin to reach the output section. Thus, is considered as a constant feature of the basin, regardless of the characteristics of rainfall. At Table 3, are listed several expressions from which it is possible to define the time of concentration for a given section of the watershed [59, 60, 84-86].

Peak flow rates

The peak flow rate is an important indicator for preliminary assessment of the flood risk [43, 87]. It can be determined based on: empirical formulas - i.e. considering the accumulated experience and the area of the watershed; kinematic formulas i.e. considering the concepts of time and concentration of critical precipitation; statistical formulas - regarding the analysis of a set of values for a given section $[88,59]$.

Based on the existing manuals - $[88,59,61-63,65,66]$ the formulas were selected based on their limitations and presented in Table 4.

Table 4. Formulas to calculate the peak flow rate.

\begin{tabular}{ll}
\hline Formula & \\
\hline Forti & $Q_{p}=A_{b} \cdot\left[b \cdot 500 /\left(A_{b}+125\right)+c\right]$ \\
Iskowski & $Q_{p}=K_{I s} \cdot m_{I} \cdot \bar{P} \cdot A_{b}$ \\
Pagliaro & $Q_{p}=A_{b} \cdot\left[2900 /\left(90+A_{b}\right)\right]$ \\
Whistler & $Q_{p}=A_{b} \cdot\left[1538 /\left(259+A_{b}\right)+0,054\right]$ \\
Rational & $Q_{p}=C \cdot I \cdot A_{b}$ \\
Giandotti & $Q_{p}=\lambda \cdot A_{b} \cdot h_{\max } / t_{c}$ \\
Mockus & $Q_{p}=2,08 \cdot A_{b} \cdot P_{e} /\left(\sqrt{t_{c}}+0,6 \cdot t_{c}\right)$ \\
Témez & $Q_{p}=C \cdot I \cdot A_{b} / 3$ \\
Average & $\overline{Q_{P}}=\left(\sum Q_{p, i}\right) / n$ \\
\hline
\end{tabular}

$\left(A_{b}\right)$ - watershed area $\left(\mathrm{km}^{2}\right)$; $(\mathrm{b}, \mathrm{c})$ - constantes; $\left(\mathrm{K}_{\mathrm{Is}}\right)$ - variable coefficient between 0.800 and 0.017 , depending on the category of soils, vegetal cover and relief; $\left(\mathrm{m}_{\mathrm{I}}\right)$ - variable coefficient with the basin area; $(\overline{\mathrm{P}})$ - average annual rainfall $(\mathrm{m})$; $(\mathrm{C})$ - coefficient of rational formula that depends on the typology and occupation of the soil of the watershed or flow coefficient of Témez formula; (I) - intensity rainfall average for a given frequency of occurrence and duration equal to the time of concentration of the watershed $(\mathrm{mm} / \mathrm{h}) ;(\lambda)$ - parameter in the function area; $\left(\mathrm{h}_{\max }\right)$ - height of precipitation for a duration equal to the time of concentration and a certain return period $(\mathrm{mm}) ;\left(\mathrm{t}_{\mathrm{c}}\right)$ - time of concentration $(\mathrm{h}) ;\left(\mathrm{P}_{\mathrm{e}}\right)$ - efective rainfall $(\mathrm{cm}) ;(\mathrm{n})$ number of used formulas.

\section{Velocity}

Depending on the velocity, it is possible to predict the existence of sediment deposition or erosion. Several authors i.e. [63]) or [67]- have defined that the minimum and maximum velocity (U) for this channel typology are 0.75 and $4.50 \mathrm{~m} / \mathrm{s}$, respectively, occurring sediment deposition if $\mathrm{U}<$ $0.75 \mathrm{~m} / \mathrm{s}$ and erosion if $\mathrm{U}>4.50 \mathrm{~m} / \mathrm{s}$.

\section{Froude and Reynolds number}

The Froude number is a dimensionless number, used in hydraulic outlets of free surfaces, representing the ratio of a characteristic speed and the speed of gravitational wave or the ratio between the forces of inertia and gravity forces, separating the runoff regime typologies into three types according to their relationship with the critical level of the water in the canal $[64,66,59,89,90]$. A way of classifying the flow is through the Froude number $\left(F_{r}\right)$, given by the equation:

$$
F_{r}=u / \sqrt{g \times h}
$$

Where:

$\mathrm{u}$ - represents the characteristic velocity $(\mathrm{m} / \mathrm{s})$;

$\mathrm{g}$ - represents the gravitational acceleration $\left(\mathrm{m} / \mathrm{s}^{2}\right)$;

$\mathrm{h}$ - represents the hydraulic depth $(\mathrm{m})$, resulting from the equation $h=A / B$ (being $A$ the cross-sectional area, $\mathrm{m}^{2}$, and $B$ the width of the free surface, $\mathrm{m}$ ).

Thus, it is possible to classify the flow as: Fluvial flow (slow), if $\mathrm{F}_{\mathrm{r}}<1$; Torrential flow (fast), if $\mathrm{F}_{\mathrm{r}}>1$; Critical flow, if $F_{r}=1[66,59]$.

According to $[62,59]$, the coefficient, number or Reynolds module (abbreviated as $\mathrm{R}_{\mathrm{e}}$ ), is a dimensionless number used in fluid mechanics, enabling the calculation of the flow regime of a given fluid on a surface. Reynolds number illustrates the importance of viscosity in the generation of a flow and, in the case of a channel, is given by the following equation:

$$
R_{e}=u \times R_{h} / v
$$

\section{Where:}

$R_{h}$ - represents the hydraulic radius $(m)$, ratio between the area of the wet section $\left(\mathrm{A}, \mathrm{m}^{2}\right)$ and the wet perimeter $(\mathrm{P}, \mathrm{m})$;

$v$ - represents the kinematic viscosity of fluid $\left(\mathrm{m}^{2} / \mathrm{s}\right)$;

So, it is possible to classify the flow as: Laminar flow, if $\mathrm{R}_{\mathrm{e}}<$ 500; Turbulent flow, if $\mathrm{R}_{\mathrm{e}}>2000$; Transitional flow, if $500<\mathrm{R}_{\mathrm{e}}<2000([59,67])$.

\section{Manning's Coefficient}

A well-knowledge of the state of the riverbed can be defined by his degree of roughness (Manning's coefficient) a critical indicator regarding the influence it has on the flow $[10,91-96]$. For a proper study of the uniformity regime in a free surface flows, is used the function of Manning, through the following equation:

$$
Q=\left(\frac{1}{n}\right) \cdot A \cdot R^{2 / 3} \cdot \sqrt{i}
$$

Where:

$\mathrm{Q}$ - flow $\left(\mathrm{m}^{3} / \mathrm{s}\right)$;

A - flow cross-section $\left(\mathrm{m}^{2}\right)$; 
$\mathrm{R}$ - hydraulic radius (m);

i - to reduced water heights, consider the channel sill slope, as to significant water heights, consider the continuous head loss;

$\mathrm{n}$ - Manning's coefficient $\left(\mathrm{m}^{-1 / 3} \mathrm{~s}\right)$.

The hydraulic radius $(\mathrm{R})$, is the quotient between the transverse section of the flow and its wet perimeter [97, 98, 59]. Thus, the $R$ value is calculated from the section's geometric characteristics. Usually, in the channel under study, we have the following equation:

$$
R=\frac{A}{P}=\frac{b \cdot h}{b+2 h}
$$

Where:

$\mathrm{P}$ - wet perimeter $(\mathrm{m})$;

$\mathrm{b}$ - rectangular section width (m);

$\mathrm{h}$ - free surface height relative to the bottom of the channel

\subsection{Probabilistic Analysis}

To perform an effective characterization of flow in a natural channel the parameters should be analysed regarding Reynolds number, the Froude number and water height obtained through different methods of modelling - essential features for a well-development of the channel design. Thus, it was necessary to calculate the time of concentration and also the subsequent calculation of the peak flow rates. However, some formulas demand to define the precipitation intensity - which is obtained through a precipitation vs duration graph, along with a probabilistic analysis (Figure 4).

Daily precipitation's data for Funchal, was obtained through the National Information System of Water Resources database (SNIRH), since it's the most complete source. Once collected, the data were organized, analysed and assessed throughout the following processes. $(\mathrm{m})$.

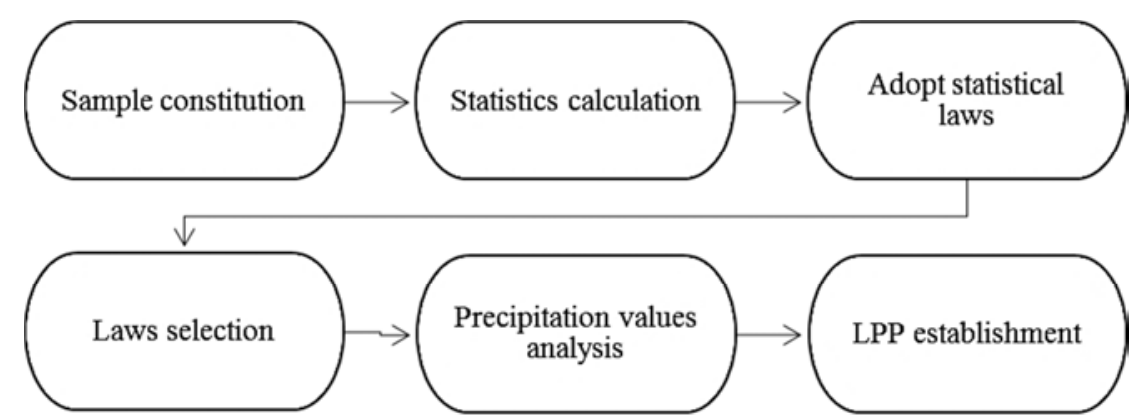

Figure 4. Phases of the probabilistic analysis.

Regarding the analysis of hydrological variable values for daily durations - the sum of 1 to 5 days - for the intended return periods (Table 5).

Table 5. Maximum precipitations for a given duration, return periods and probabilistic laws.

\begin{tabular}{lllll}
\hline \multirow{2}{*}{ Duration (hours) } & \multirow{2}{*}{ Law } & \multicolumn{4}{l}{ Maximum annual precipitation $(\mathbf{m m})$} \\
\cline { 3 - 5 } & & $\mathbf{1 0}$ Years & $\mathbf{1 0 0}$ Years & $\mathbf{1 0 0 0}$ Years \\
\hline 24 & Galton & 165.72 & 248.60 & 334.42 \\
48 & Gumbel & 218.06 & 311.71 & 403.67 \\
72 & Gumbel & 257.46 & 365.98 & 472.53 \\
96 & Gumbel & 288.68 & 407.32 & 523.81 \\
120 & Galton & 321.92 & 447.94 & 570.31 \\
\hline
\end{tabular}

So, based on pairs of values and laws selection, it has considered a return period of 100 years, enabling to define a Line of Pluviometric Possibility (LPP) (Figure 5).

\section{LPP for $T=100$ years}

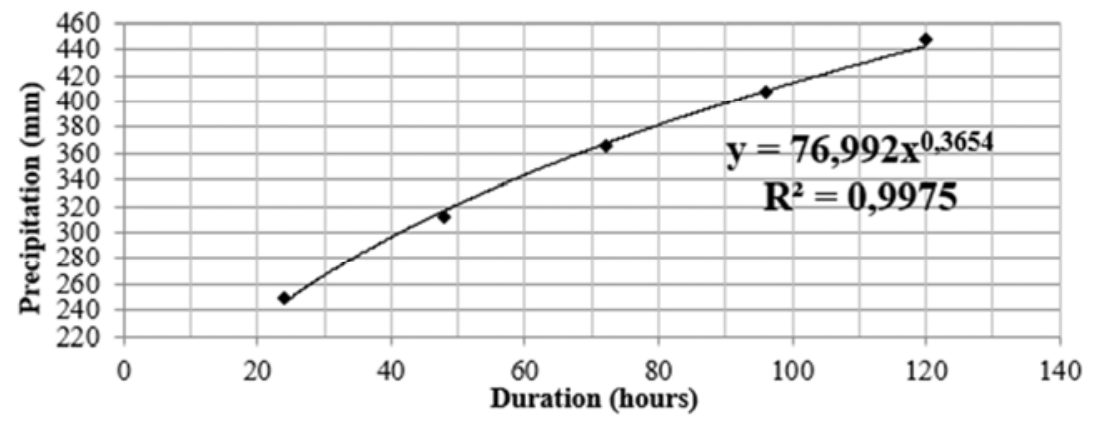

Figure 5. LPP for a 100 years return period. 
Through the analysis of the LPP, along with formula selection, it is possible to calculate the precipitation values and, consequently, their intensity.

Peak flow rates values

The obtained values for the different formulas have disparities between them, in fact, those disparities may be explained by the core used to develop the formulas. So, to minimize such disparities, it has been determined the average value of the flow rate - which is used for calculation, simulation, and modelling (Table 6). Also, pre-established values of coefficients were adopted (Table 7).

Table 6. Peak flow rates.

\begin{tabular}{lcll}
\hline \multicolumn{2}{l}{ Peak flow rates for the studied watersheds } & & Santa Luzia \\
\hline Parameter & São João & & João Gomes \\
\hline Flow $\left(\mathbf{m}^{\mathbf{3} / \mathbf{s})}\right.$ & & 127.892 & 114.588 \\
\hline Forti & 133.049 & 190.241 & 169.359 \\
Iskowski & 198.404 & 397.963 & 358.221 \\
Pagliaro & 413.267 & 81.326 & 72.489 \\
Whistler & 84.777 & 664.949 & 601.589 \\
Rational & 670.879 & 347.747 & 322.576 \\
Giandotti & 331.810 & 335.147 & 302.129 \\
Mockus & 336.907 & 338.297 & 306.062 \\
Témez & 341.314 & $\mathbf{3 1 0 . 4 4 5}$ & $\mathbf{2 8 0 . 8 7 7}$ \\
Average & $\mathbf{3 1 3 . 8 0 1}$ & & \\
\hline
\end{tabular}

Table 7. Adopted values for formulas used to calculate the flow rate.

\begin{tabular}{ll}
\hline Formulas & Adopted values \\
\hline Forti & $\mathrm{b}, \mathrm{c}-$ constants that have, respectively, the values of 3.25 and 1.00 for a maximum daily precipitation between $200 \mathrm{~mm}$ and $400 \mathrm{~mm}$ \\
Iskowski & $\mathrm{K}_{\mathrm{Is}}$ - for category IV, takes the value of $0.6 ; \mathrm{m}_{\mathrm{I}}-$ interpolated value between 10 and $40 \mathrm{~km}^{2}$ \\
Rational & $\mathrm{C}$ - residential zone - houses in the town center, takes the value $0.5 ; \mathrm{C}_{\mathrm{f}}-$ for a return period of 100 years, takes the value 1.25 \\
Giandotti & $\lambda$ - takes the value 0.346, because the watershed areas are less than $300 \mathrm{~km}^{2}$ \\
Témez & $\mathrm{C}=0.926 ; \mathrm{P}_{0}=5.644 ; \mathrm{CN}_{\mathrm{II}}=90 ; \mathrm{CN}_{\mathrm{III}}=95.392$ \\
\hline
\end{tabular}

\subsection{Modelling}

Before starting modelling (Table 8) it was necessary to identify the riversides selected as case studies. The analysis has considered the Manning's coefficient (artificial turf and natural rockfill, both depict the vegetation cover, rocks, aggregates and coarse material found in the coating of the riverside of Funchal - (Figure 6)) and other features, such as: longitudinal slope, flow normal height for different rates, flow curves and specific energy.
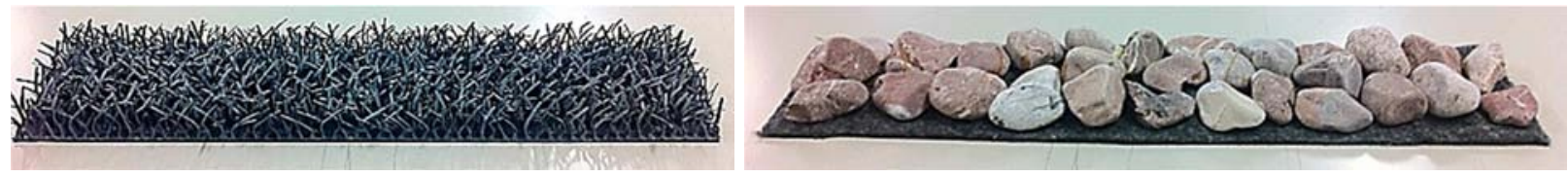

Figure 6. Artificial turf and natural rockfill.

For a fast flow, upstream controlled, the adopted boundaries conditions for each model, are: Programmed spreadsheet, and HEC-RAS program - upstream height is equal to the critical height; Experimental model - upstream height is equal to the value of the first point reading.

Table 8. Modelling.

\begin{tabular}{ll}
\hline Modelling & Description \\
\hline $\begin{array}{l}\text { Programmed } \\
\text { spreadsheet }\end{array}$ & $\begin{array}{l}\text { To determine backwater curves - programmed in Visual Basic, "programming language" - have been based on pre-established } \\
\text { spreadsheets. The performed tasks by the program, are an iterative process, once they adopt the finite difference method with successive } \\
\text { approximations until it reaches the pre-established tolerance. Limitation: Applicable only to rectangular and trapezoidal sections, with or } \\
\text { without width reduction/increase, constant slope and flow; in this case, does not compute sediment transport. }\end{array}$ \\
$\begin{array}{l}\text { Integrated software systems that allow evaluating dimensional flows, in natural or natural channels, as well as to assess the sediment } \\
\text { transport degrees and even their water quality. The system consists of: a Graphical User Interface (GUI), hydraulic analysis components, } \\
\text { capabilities to store and manage data, graphs, and reporting capabilities. Limitation: Performance based on previous information collected } \\
\text { program } \\
\text { in the stream (mainly water height) which, at the time, didn't exist. }\end{array}$ \\
$\begin{array}{l}\text { A multifunction channel is a base unit that offers a wide range of experiences related to hydraulic engineering. After adjusting the } \\
\text { inclination and flow values, it should be used equipment that allows measuring, enabling to obtain values of water height at the pre- } \\
\text { extablished points. The value of the water height is given by the average between the obtained values in each test. Limitation: Applicable } \\
\text { model }\end{array}$ &
\end{tabular}




\section{Results}

The obtained outcomes correspond to flows study performed through the programmed spreadsheet, HEC-RAS program and experimental model - regarding to São João river, mixed coating (artificial turf and natural rockfill) (Table 9). The remaining studied sections - Santa Luzia, João
Gomes and their junction - have followed a similar procedure, leading to similar conclusions.

Attending to the limitations of each model, the only parameters that can be compared between each method are water height (h), Manning's roughness coefficient (n), Froude and Reynolds numbers (Fr and Re), which are in bold in Table 9.

Table 9. Summary of the outcomes for the São João river section, mixed coating.

\begin{tabular}{|c|c|c|c|c|c|c|c|c|c|}
\hline \multicolumn{10}{|c|}{ São João river section - mixed coating } \\
\hline \multicolumn{10}{|c|}{ Programmed spreadsheet } \\
\hline Section & $\mathrm{L}(\mathrm{m})$ & $\mathrm{b}(\mathrm{m})$ & $\mathrm{h}(\mathrm{m})$ & $\mathrm{Q}\left(\mathrm{m}^{3} / \mathrm{s}\right)$ & $\mathrm{U}(\mathrm{m} / \mathrm{s})$ & $\mathrm{i}(\mathrm{m} / \mathrm{m})$ & $\mathrm{n}\left(\mathrm{m}^{-1 / 3} \mathrm{~s}\right)$ & $\mathrm{Fr}$ & $\operatorname{Re}$ \\
\hline Upstream & 0 & 10 & 4.603 & 313.801 & 6.818 & 0.03 & 0.032 & 1.015 & 16177729.050 \\
\hline Downstream & 23.2 & 10 & 2.716 & 313.801 & 11.553 & 0.03 & 0.028 & 2.239 & 20132432.630 \\
\hline \multicolumn{10}{|l|}{ HEC-RAS } \\
\hline Section & $\mathrm{L}(\mathrm{m})$ & $\mathrm{b}(\mathrm{m})$ & $\mathrm{h}(\mathrm{m})$ & $\mathrm{Q}\left(\mathrm{m}^{3} / \mathrm{s}\right)$ & $\mathrm{U}(\mathrm{m} / \mathrm{s})$ & $\mathrm{i}(\mathrm{m} / \mathrm{m})$ & $\mathrm{n}\left(\mathrm{m}^{-1 / 3} \mathrm{~s}\right)$ & $\mathrm{Fr}$ & $\operatorname{Re}$ \\
\hline Downstream & 23.2 & 10 & 2.950 & 313.801 & 10.637 & 0.03 & 0.038 & 1.978 & 19540506.881 \\
\hline \multicolumn{10}{|c|}{ Experimental model } \\
\hline Section & $\mathrm{L}(\mathrm{m})$ & $\mathrm{b}(\mathrm{m})$ & $\mathrm{h}(\mathrm{m})$ & $\mathrm{Q}\left(\mathrm{m}^{3} / \mathrm{h}\right)$ & $\mathrm{U}(\mathrm{m} / \mathrm{s})$ & $\mathrm{i}(\mathrm{m} / \mathrm{m})$ & $\mathrm{n}\left(\mathrm{m}^{-1 / 3} \mathrm{~s}\right)$ & $\mathrm{Fr}$ & $\operatorname{Re}$ \\
\hline Upstream & 0 & 0.086 & 0.0737 & 9.500 & 0.417 & 0.03 & 0.038 & 0.490 & 11197.548 \\
\hline Downstream & 2.32 & 0.086 & 0.0567 & 9.500 & 0.541 & 0.03 & 0.027 & 0.727 & 13107.498 \\
\hline \multicolumn{10}{|c|}{ Experimental model (after processing) } \\
\hline Section & $\mathrm{L}(\mathrm{m})$ & $\mathrm{b}(\mathrm{m})$ & $\mathrm{h}(\mathrm{m})$ & $\mathrm{Q}\left(\mathrm{m}^{3} / \mathrm{s}\right)$ & $\mathrm{U}(\mathrm{m} / \mathrm{s})$ & $\mathrm{i}(\mathrm{m} / \mathrm{m})$ & $\mathrm{n}\left(\mathrm{m}^{-1 / 3} \mathrm{~s}\right)$ & $\mathrm{Fr}$ & $\operatorname{Re}$ \\
\hline Downstream & 23.2 & 10 & 3.260 & 313.801 & 9.715 & 0.03 & 0.037 & 1.719 & 18979256.833 \\
\hline
\end{tabular}

Regarding the parameters that characterize the flow (Fr and $\mathrm{Re}$ ), all the models present, at the downstream section, $\mathrm{Fr}>1$ and $\operatorname{Re}>2000$, i.e. a fast and turbulent flow, distinctive of a flood. In the experimental model, the Froude number is lesser than 1 at the upstream section, explained by a slower flow at the inflow segment.

The Manning's roughness coefficient for the spreadsheet decreases from 0.032 to 0.028 due to the decrease of water height, as in HEC-RAS program the value 0.038 doesn't change because it's a pre-assigned value before each simulation.

In the experimental model, the upstream value of Manning's roughness coefficient is significantly higher than the spreadsheet due to the different materials that constitute the experimental model (acrylic walls, stainless-steel bottom and mixed coating (artificial turf and natural rockfill)) and scale effects, whereas the other two models consider the initial value of 0.032 or 0.038 , corresponding to the mixed coating (artificial turf and natural rockfill).

The water height varies from model to model, but the only values we can use, for design or decision-making purposes, are the ones regarding the spreadsheet.

The reason of the previous statement is that HEC-RAS doesn't consider the variation of the Manning's roughness coefficient, unless measurements of water height are available, allowing the correction of n, which didn't exist at the time; and the bottom of the experimental model at the inflow segment is higher than the study section, as the outflow segment suffers a sudden decrease, producing a higher value upstream and a lower one downstream, compared to the other two models.

The following graphs (Figures 7, 8, and 9) represents the different used methods of analysis containing: energy line (E), free surface elevation (Y), bottom elevation $(\mathrm{Z})$, and roughness coefficient $(\mathrm{Ks})$.

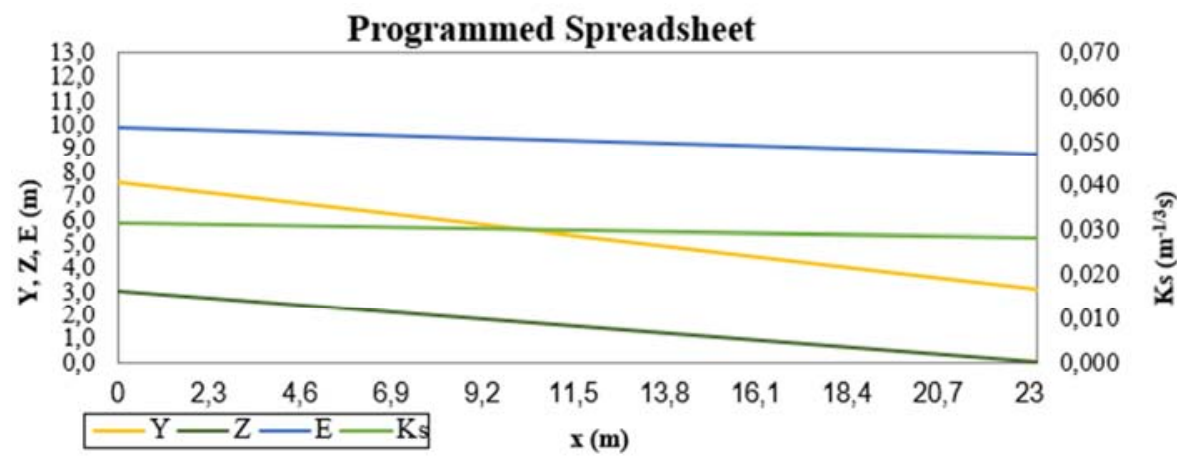

Figure 7. Outcomes for the programmed spreadsheet for São João section - mixed coating. 


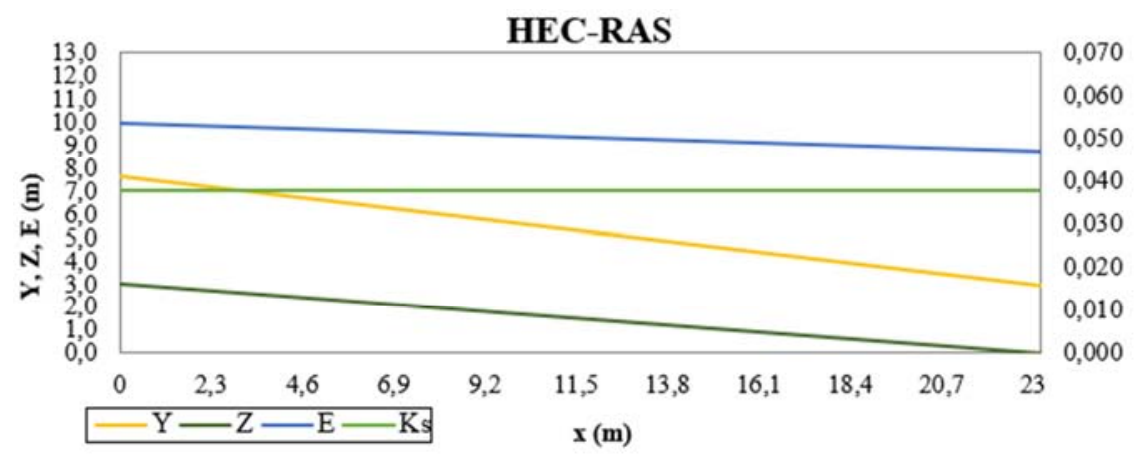

Figure 8. Outcomes for the HEC-RAS program for São João section - mixed coating.

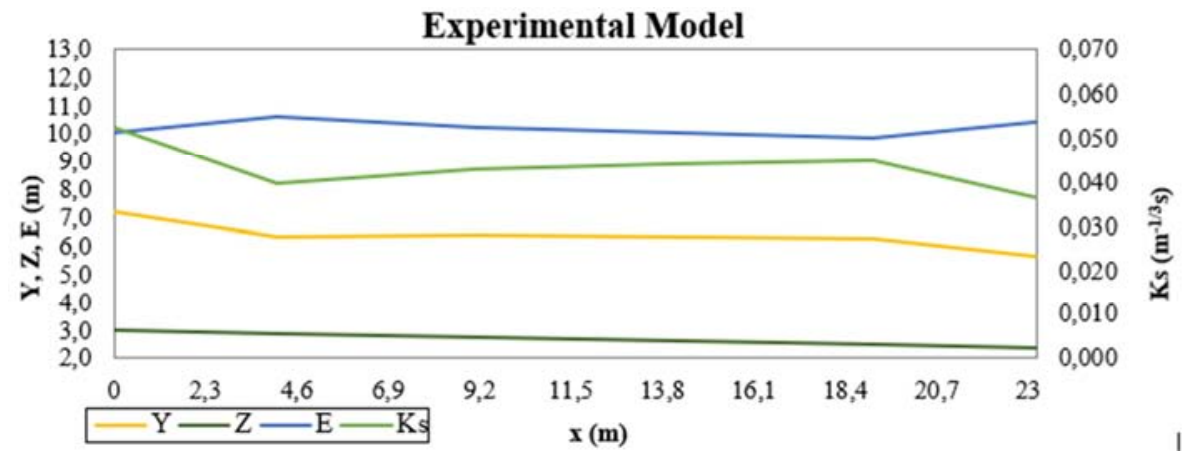

Figure 9. Outcomes for the experimental model for São João section - mixed coating.

Regarding the quality of the results, the better outcome is from the spreadsheet, followed by the HEC-RAS program and the experimental model.

The HEC-RAS performance depends on the information collected in streams, such as water height, which is used to calibrate the model; as such doesn't exist, the model results cannot be used.

Through the analysis of the graphs, the bottom elevation as the free surface elevation and the energy line decreases progressively from upstream to downstream, as velocity increases in that same direction.

The experimental model has an imperfection in its bottom that occurs midway, causing the effects observed in Figure 9, influencing the outcome and its usefulness.

Regarding velocity (Table 9), although there is no sediment deposition $(\mathrm{U}>0.75 \mathrm{~m} / \mathrm{s})$, still, there is sediment transport and consequently erosion of walls and bottom of the channel as the velocity exceeds the maximum value.

\section{Discussion and Conclusion}

The case study develops around sections of pre-existing channels constructed after the event of February 20, 2010, aiming to characterize the flow and obtain water heights due to a flood with a return period of 100 years, based on three different models and accomplished, with satisfactory results, by the programmed spreadsheet model, ideal for situation of scarce data and/or resources [99-105].

Along the research, a programmed spreadsheet was created to determine backwater curves based on previous existing sheets, presenting limitations such as: applicable only to rectangular and trapezoidal sections with constant slope and flow, i.e. for geometrically simple study case as this one. Nonetheless, it presented the best outcome justified by its data requirement (geometric data and resulting data from precipitation analysis), simplicity, low time consuming and cost, compared to the other two models [99-105].

Through the HEC-RAS program, it is possible to reach a larger and varied range of analyses in comparison with the programmed spreadsheet, as well as the insertion of parameters that the programmed spreadsheet does not consider (i.e. sediment transport), useful for complex cases. However, the model needs calibration obtained from data collected in streams (unfortunately non-existent at the time) and it's a time-consuming process, doesn't compensate using it in this situation [99-105].

The experimental model enables to verify the influence that some hydraulic infrastructures have on the flow. However, considering the absence of such infrastructures, the effects of scale reduction in comparison with the other previously mentioned methods, its cost and test time, doesn't compensate using it in this situation [16, 99-106].

Regarding the water height, combining the section height and the water height, along with the channel, it's possible to verify if the channel is prepared for this event and identify possible errors and liabilities. Furthermore, considering the time it takes the sediments to settle in the bottom of the channel and its height, it's possible to establish an adequate maintenance period to remove these sediments [79, 107$112]$.

The present study has defined, as well as previously 
researches - i.e. [10-20], are some of the examples - that in fact, there are specific core guidelines regarding the prevention and mitigation of floods.

Through the analysis of Funchal's unsuccessful example and its consequences, involving urban planning and land management considerable errors, some basic guidelines are exposed: avoid further constructions inside the riverbanks or floodplains (mostly upstream); promote punctual accesses to the riverbed guaranteeing its cleaning (keeping the projected depth); foster a change of land use policies - mainly for areas where it is impossible to widen the channel, due to previous land occupation; act on riverbanks and their surrounding areas in order to prevent future landslides into the streams; develop engineering strategies for impermeable areas, near the streams, leading to a consequently reduce the flow [79, 107-114].

So, if the previous measures substantiated, in similar study cases, by a simple programmed spreadsheet are considered, by planners, main actors, and decision-makers, it leads towards safer and sustainable cities.

\section{References}

[1] Konrad, C. P. (2003). Effects of Urban Development on Floods. USGS Numbered Series - Report 076-03, 4 p.. doi: $10.3133 /$ fs 07603 .

[2] Linmei, N., Oddvar, L., Geir, L. \& Elisabeth, S. (2009) Impacts of climate change on urban drainage systems - a case study in Fredrikstad, Norway, Urban Water Journal, 6: 4, 323332. doi: 10.1080/15730620802600924.

[3] Granados-Olivas, A., Alatorre-Cejudo, L., Adams, D., Serra, Y., Esquivel-Ceballos, V., Vazquez-Galvez, F., Eastoe, C. (2016). Runoff Modeling to Inform Policy Regarding Development of Green Infrastructure for Flood Risk Management and Groundwater Recharge Augmentation along an Urban Subcatchment, Ciudad Juarez, Mexico. In Journal of Conteporary Water Research \& Education (Vol. 159, pp. 5061). Wiley, 111 River ST, Hoboken 07030-5774, NJ USA. doi: 10.1111/j.1936-704X.2016.03229.x.

[4] Majewski, W. (2016). Urban flash flood in Gdansk - 2001. Case study. In Meteorology Hydrology and Water Management-Research and Operational Applications (2 ed., Vol. 4, pp. 41-49). Warsaw, Poland: Institute of Meteorology \& Water Management. doi: 10.26491/mhwm/64636.

[5] Rodriguez-Morata, C., Ballesteros-Cánovas, J., Trappmann, D., Beniston, M., \& Stoffel, M. (2016). Regional reconstruction of flash flood history in the Guadarrama range (Central System, Spain). Science.

[6] Kourgialas, N. N., \& Karatzas, G. P. (2017). A national scale flood hazard mapping methodology: The case of Greece Protection and adaptation policy approaches. Science of the Total Environment, 441-452. doi: 10.1016/J.SCITOTENV.2017.05.197.

[7] Mahmood, M. I., Elagib, N. A., Horn, F., \& Saad, S. A. (2017). Lessons learned from Khartoum flash flood impacts: An integrated assessment. Science of the Total Environment, 1031-1045. doi: 10.1016/j.scitotenv.2017.05.260.
[8] Recanatesi, F., Petroselli, A., Ripa, M. N., \& Leone, A. (2017). Assessment of stormwater runoff management practices and BMPs under soil sealing: A study case in a periurban watershed of the metropolitan area of Rome (Italy). Journal of Environmental Management, 6-18. doi: 10.1016/J.JENVMAN.2017.06.024.

[9] Nie, L., Linholm, O., Lindholm, G., Syversen, E., (2009). Impacts of climate change on urban drainage systems- a case study in Fredrikstad, Norway. Urban Water Journal, 6 (4), 323-332. doi: 10.1080/15730620802600924.

[10] Correia, C. M. (2007, maio). Boas Práticas para Ocupação do Solo, no respeito pelos Recursos Hídricos. Comissão de Coordenação e Desenvolvimento Regional de Lisboa e Vale do Tejo.

[11] Semadeni-Davies, A., Hernebring, C., Svensson, G., Gustafsson, L. (2008). The impacts of climate change and urbanization on drainage in Helsingborg, Sweden: Suburban stormwater. Journal of Hydrology, 350, 114-125. doi: 10.1016/j.jhydrol.2007.11.006.

[12] Watt, W. E., Waters, D., and McLean, R. 2003. Climate change and urban stormwater infrastructure in Canada: context and case studies. Hydrology Research Group, Department of Civil Engineering, Queen's University.

[13] Grum, J., H., Jorgensen, M., Johansen, A., T., Linde, R. M. (2006). The effect of climate change on urban drainage: An evaluation based on regional climate model simulations. Water Science \& Technology 54 (67), 9-17. doi: 10.2166/wst.2006.592.

[14] Jovanovic, T., Mejía, A., Gall, H., \& Gironás, J. (2014). Effect of urbanization on the long-term persistence of streamflow records. Physica A, 208-221. doi: 10.1016/J.PHYSA.2015.12.024.

[15] Mailhot, A., Duchesne, S. (2010). Design criteria of urban drainage infrastructures under climate change. Journal of Water Resources Planning and Management, 136, 201-208. doi: 10.1061/(ASCE)WR.1943-5452.0000023.

[16] Arisz H, Burrell, B. C. (2006). Urban drainage infrastructure planning and design considering climate change. Proceedings of EIC Climate Change Technology Conference 2006, Engineering Institute of Canada (EIC), Ottawa Congress Center, 9-12 May, 1-9. doi: 10.1109/EICCCC.2006.277251.

[17] Muis, S., Güneralp, B., Jongman, B., Aerts, J. C., \& Ward, P. J. (2015). Flood risk and adaptation strategies under climate change and urban expansion: A probabilistic analysis using global data. Science of the Total Environment, 445-457. doi: 10.1016/J.SCITOTENV.2015.08.068.

[18] Petit-Boix, A., Sevigné-Itoiz, E., Rojas-Gutierrez, L. A., Barbassa, A. P., Josa, A., Rieradevall, J., \& Gabarrell, X. (2017). Floods and consequential life cycle assessment: Integrating flood damage into the environmental assessment of stormwater Best Management Practices. Journal of Cleaner Production, 601-608. doi: 10.1016/J.JCLEPRO.2017.06.047.

[19] Hengeveld, H. G. (2000). Projections for Canada's climate future. A discussion of recent simulations with the Canadian Global Climate Model. Editor: David Francis of Lanark House Communications (Toronto). Meteorological Service of Canada, Environment Canada; Downsview, Ontario, ISBN 0-662-64900-1, ISSN 0835-3980the, Minister of Public Works and Government Services Canada, Catalogue No. En57-2000-01E, 32 p. 
[20] Jenkins, K., Surminski, S., Hall, J., \& Crick, F. (2017). Assessing surface water flood risk and management strategies under future climate change: Insights from an Agent-Based Model. Science of the Total Environment, 159-168. doi: 10.1016/J.SCITOTENV.2017.03.242.

[21] Didón, L., 1995. Plan-och bygglagen 1987: 10 (Planning and Building law - Swedish).

[22] Fernandes, J. P., \& Cruz, C. S. (2011). Limpeza e Gestão de Linhas de Água (Vol. III). EPAL - Empresa Portuguesa das Águas Livres, S. A.

[23] Morgan, A., B. Branfireun \& F. Csillag. (2004). An Evaluation of the Contributions of Urbanization and Climatic Change to Runoff Characteristics in the Laurel Creek Watershed, Ontario. Canadian Water Resources Journal, Vol. 29 (3): 171-182. doi: 10.4296/cwrj171.

[24] Oliveira, R. P., Almeida, A. B., Sousa, J., Pereira, M. J., Portela, M. M., Coutinho, M. A., Lopes, S. (2011). A avaliação do risco de aluviões na ilha da Madeira. $10^{\circ}$ Simpósio de Hidráulica e Recursos Hidricos dos Países de Língua Oficial Portuguesa (10 SILUSBA) (pp. 1-20). IST, UMa \& LREC. Retrieved from https://www.researchgate.net/publication/244994405.

[25] Konig, A., Sægrov, S., and Schilling, W. (2002). Damage assessment for urban flooding. In: Proceedings of the Ninth International Conference on Urban Drainage, 8-13 Sept, 2002, Portland, Oregon, USA.

[26] Madsen, A. B. (2007). Flood damage and discharge of pollution in the city of Bergen - Analysis of the effect of climate change. MSc. thesis. University of Life Science and Technology.

[27] Nie, L. (2004). Flooding analysis of urban drainage systems. Ph. D. thesis. Norwegian University of Science and Technology.

[28] O'Sullivan, A. D., Wicke, D., Hengen, T. J., Sieverding, H. L., \& Stone, J. J. (2015). Life Cycle Assessment modelling of stormwater treatment systems. Journal of Environmental Management, 236-244. doi: 10.1016/J.JENVMAN.2014.10.025.

[29] Ravansalar, M., Rajaee, T., \& Kisi, O. (2017). Wavelet-linear genetic programming: A new approach for modeling monthly streamflow. Journal of Hydrology, 461-475. doi: 10.1016/J.JHYDROL.2017.04.018.

[30] Vevatne, J. and Westskog, H. eds. (2007). Adaptation to climate change in the Oslo region (in Norwegian). Centre for Interdisciplinary Environment and Social research (CIENS), report No. 2007: 01.

[31] Carvalho, A. M. Galopim de, e BRANDÃO, José M. (1991) Geologia do Arquipélago da Madeira, Lisboa, Museu Nacional de História Natural, Lisboa.

[32] Quintal, Raimundo \& Vieira, Maria José (1985) - Ilha da Madeira - Esboço de geografia física, Funchal, Secretaria Regional do Turismo e Cultura.

[33] Quintal, Raimundo (1999) - Aluviões da Madeira: séculos XIX e XX. Associação Portuguesa de Riscos, Prevenção e Segurança. doi: https://doi.org/10.14195/1647-7723_6_4.

[34] Fowler, A. (1999). Potential climate change impacts on water resources in the Aukland Region (New Zealand). Climate Research, Vol. II, 221-245.
[35] Lindholm, O. (2007). Who should pay for water damage? (in Norwegian). Today's Business - water, wastewater and sanitation, 4 .

[36] Hammond, M. J., Chen, A. S., Djordjevic, S., Butler, D., \& Mark, O. (2013). Urban flood impact assessment: A state-ofthe-art review. Urban Water Journal. doi: $10.1080 / 1573062 X .2013 .857421$.

[37] Rossel, F., Gironás, J., Mejía, A., Rinaldo, A., \& Rodriguez, F. (2014). Spatial characterization of catchment dispersion mechanisms in an urban context. Advances in Water Resources, 290-301. 10.1016/J.ADVWATRES.2014.09.005.

[38] Mejía, A., Rossel, F., Gironás, J., \& Jovanovica, T. (2015). Anthropogenic controls from urban growth on flow regimes. Advances in Water Resources, 125-135. doi: 10.1016/J.ADVWATRES.2015.08.010.

[39] Mitková, V. B., Pekárová, P., Miklánek, P., \& Pekár, J. (2016). Hydrological simulation of flood transformations in the upper Danube River: Case study of large flood events. Journal of Hydrology and Hydromechanics, 337-348. doi: 10.1515/johh2016-0050.

[40] Röthlisberger, V., Zischg, A. P., \& Keiler, M. (2017). Identifying spatial clusters of flood exposure to support decision making in risk management. Science of the Total Environment, 593-603. 10.1016/J.SCITOTENV.2017.03.216.

[41] Alexis Morgan, Brian Branfireun \& Ferenc Csillag (2004). An Evaluation of the Contributions of Urbanization and Climatic Change to Runoff Characteristics in the Laurel Creek Watershed, Ontario, Canadian Water Resources Journal / Revue canadienne des ressources hydriques, 29: 3, 171-182. doi: $10.4296 /$ cwrj171.

[42] Zhang, X. B., K. D. Harvey, W. D. Hogg and T. R. Yuzyk. 2001. "Trends in Canadian Streamflow." Water Resources Research, 37 (4): 987-998.

[43] Mojaddadi H, Pradhan B, Nampak H, Ahmad N, Ghazali AHB (2017). Ensemble machine-learning-based geospatial approach for flood risk assessment using multi-sensor remotesensing data and GIS. Geomatics Nat Hazard Risk 8: 1080 1102 .

[44] Tehrany MS, Pradhan B, Jebur MN (2013). Spatial prediction of flood susceptible areas using rule based decision tree (DT) and a novel ensemble bivariate and multivariate statistical models in GIS. J Hydrol 504: 69-79.

[45] Carmo, J. S. (2004). Modelação em hidráulica fluvial e ambiente. Coimbra: Imprensa da Universidade. doi: 10.14195/978-989-26-0364-3.

[46] Amador, M. d. (2010). Tipos de métodos científicos. Lisboa: FCSH, Universidade Nova de Lisboa. Retrieved from http://www.fcsh.unl.pt/docentes/cceiaold/images/stories/discip linas/PhD\%20Didactica\%20LE/tipos_met_cientificos.pdf.

[47] Kabiri, F., Afzalimehr, H., \& Sui, J. (2017). Flow structure over a wavy bed with vegetation cover. International Journal of Sediment Research, 186-194. doi: 10.1016/j.ijsrc.2016.07.004.

[48] Liu, C., Shan, Y., Liu, X., Yang, K., \& Liao, H. (2016). The effect of floodplain grass on the flow characteristics of meandering compound channels. Journal of Hydrology, 1-17. doi: 10.1016/J.JHYDROL.2016.07.037. 
[49] Rojas R, Feyen L, Bianchi A, Dosio A (2012). Assessment of future flood hazard in Europe using a large ensemble of biascorrected regional climate simulations. J Geophys Res Atmos 117: D17109. https://doi.org/10.1029/2012JD017461.

[50] Sampson CC, SmithAM, Bates PD, Neal JC, Alfieri L, Freer JE (2015). A high-resolution global flood hazard model. Water Resour Res 51: 7358-7381.

[51] Khosravi K, Nohani E, Maroufinia E, Pourghasemi HR (2016a). A GISbased flood susceptibility assessment and its mapping in Iran: a comparison between frequency ratio and weights-of-evidence bivariate statisticalmodels withmulticriteria decision-making technique. Nat Hazards. https://doi.org/10.1007/s11069-016-2357-2.

[52] Khosravi K, Pourghasemi HR, Chapi K, Bahri M (2016b). Flash flood susceptibility analysis and its mapping using different bivariate models in Iran: a comparison between Shannon's entropy, statistical index, and weighting factor models. EnvironMonit Assess 188: 656.

[53] Lim J, Lee K (2017). Investigating flood susceptible areas in inaccessible regions using remote sensing and geographic information system. Environ Monit Assess 189: 96.

[54] Abbaszadeh P (2016). Improving hydrological process modeling using optimized threshold-based wavelet de-noising technique. Water Resour Manag 30 (5): 1701-1721.

[55] Danandeh Mehr A, Kahya E (2017). A Pareto-optimal moving average multigene genetic programming model for daily streamflow prediction. J Hydrol 549: 603-615.

[56] Nourani V, Tahershamsi A, Abbaszadeh P, Shahrabi J, Hadavandi E (2014). A new hybrid algorithm for rainfallrunoff process modeling based on the wavelet transform and genetic fuzzy system. J Hydroinf 16 (5): 1004-1024.

[57] Hong H, Panahi M, Shirzadi A, Ma T, Liu J, Zhu A, ChenW, Kougias I, Kazakis N (2017). Flood susceptibility assessment in Hengfeng area coupling adaptive neuro-fuzzy inference system with genetic algorithm and differential evolution. doi: https://doi.org/10.1016/j.scitotenv.2017.10.114.

[58] Guo E, Zhang J, Ren X, Zhang Q, Sun Z (2014). Integrated risk assessment of flood disaster based on improved set pair analysis and the variable fuzzy set theory in central Liaoning Province China. Nat Hazards 74 (2): 947-965.

[59] Lousada, S., Camacho, R. F. (2018). Hidrologia, Recursos Hídricos e Ambiente - Aulas Teóricas. ISBN 978-989-880533-1 (V. 1), Universidade da Madeira, Funchal, Portugal. http://hdl.handle.net/10400.13/2132.

[60] Mata-Lima, H., Vargas, H., Carvalho, J., Gonçalves, M., Caetano, H., Marques, A., \& Raminhos, C. (2007). Comportamento hidrológico de bacias hidrográficas: integração de métodos e aplicação a um caso de estudo. REM - Revista Escola de Minas, 525-536. doi: 10.1590/S037044672007000300014.

[61] Martins, C. M., Mendes, M. d., Abreu, J. M., Almeida, J. P., Lima, J. P., \& Lima, I. P. (2010). Curso técnico n. ${ }^{\circ}$ 1: Hidrologia urbana - Conceitos básicos. Lisboa: Entidade Reguladora dos Serviços de Águas e Resíduos. Universidade de Coimbra.

[62] Falkovich, G. (2011). Fluid Mechanics. Cambridge University Press.
[63] Tomaz, P. (2011). Cálculos Hidrológicos e Hidráulicos para Obras Municipais (2 ed.). Navegar.

[64] Ebtehaj, I., Bonakdari, H., Zaji, A. H., Bong, C. H., \& Ghani, A. A. (2016). Design of a new hybrid natural neural network method based on decision trees for calculating the Froude number in rigid rectangular channels. Journal of Hydrology and Hydromechanics, 252-260. doi: 10.1515/johh-20160031.

[65] Singh, V. P. (2016). Handbook of Applied Hydrology, Second Edition. New York: McGraw Hill Professional, 2016.

[66] Governments, D. R., \& Engineers, W. M. (2017). Urban Storm Drainage Criteria Manual. Denver, Colorado: WrightMcLaughlin Engineers.

[67] Schlichting, H., \& Gersten, K. (2017). Boundary-Layer Theory (9 ed.). Springer-Verlag Berlin Heidelberg. doi: 10.1007/978-3-662-52919-5.

[68] Das S, Gupta A, Ghosh S (2017). Exploring groundwater potential zones using MIF techniques in semi-arid region: a case study of Hingoli district, Maharashtra. Spat Inf Res 25 (6): 749-756. https://doi.org/10.1007/s41324-017-0144-0.

[69] Das S, Pardeshi SD, Kulkarni PP, Doke A (2018). Extraction of lineaments from different azimuth angles using geospatial techniques: a case study of Pravara basin, Maharashtra, India. Arab J Geosci 11: 160. https://doi.org/10.1007/s12517-0183522-6.

[70] Dou X, Song J, Wang L, Tang B, Xu S, Kong F, JiangX (2017). Flood risk assessment and mapping based on a modified multi-parameter flood hazard index model in the Guanzhong Urban Area, China. Stoch Environ Res Risk Assess 32: 1131-1146. https://doi.org/10.1007/s00477-0171429-5.

[71] Su W, Zhang X, Wang Z, Su X, Huang J, Yang S, Liu S (2011). Analyzing disaster-forming environments and the spatial distribution of flood disasters and snow disasters that occurred in China from 1949 to 2000. Math Comput Model 54 (3-4): 1069-1078.

[72] Yin, R. K. (1994). Case Study Research: Design and Methods. London: SAGE Publications.

[73] Levy, J. S. (2008). Case Studies - Types, Designs and Logics of Inference. Conflict Management and Peace Science, 1-18. doi: 10.1080/07388940701860318.

[74] França, J. A., \& Almeida, A. B. (2003). Plano regional de água da Madeira. Síntese do diagnóstico e dos objectivos. $6^{\circ}$ SILUSBA - Simpósio de Hidráulica e Recursos Hídricos dos Países de Língua Oficial Portuguesa (pp. 751-818). Cidade da Praia, República de Cabo Verde: APRH. Retrieved from http://dramb.govmadeira.pt/berilio/docs/fileload/2FURD01510.pdf.

[75] Ribeiro, M. L., \& Ramalho, M. (2009). Uma Visita Geológica ao Arquipélago da Madeira. Lisboa: Direção Regional do Comércio, Indústria e Energia e Laboratório Nacional de Energia e Geologia, I. P.

[76] Brum da Silveira, A., Madeira, J., Ramalho, R., Fonseca, P., Rodrigues, C., \& Prada, S. (2010). Carta Geológica da ilha da Madeira na escala 1: 50.000. Folha A e B. Região Autónoma da Madeira: Secretaria Regional do Ambiente e Recursos Naturais. 
[77] Ramalho, R., Brum da Silveira, A., Fonseca, P., Madeira, J., Cosca, M., Cachão, M., Prada, S. (2015). The emergence of volcanic oceanic islands on a slow-moving plate: The example of Madeira Island, NE Atlantic. Geochemistry Geophysics Geosystems, 522-537. doi: 10.1002/2014GC005657.

[78] Pullen, J., Caldeira, R., D. Doyle, J., May, P., \& Tomé, R. (2017). Modeling the air-sea feedback system of Madeira Island. Journal of Advances in Modeling Earth Systems, 1-24. doi: 10.1002/2016MS000861.

[79] Baioni, D. (2011). Human activity and damaging landslides and floods on Madeira Island. Natural Hazards and Earth System Sciences, 3035-3046. doi: 10.5194/nhess-11-30352011.

[80] Lopes, S. (2011). A utilização do SIG na estimativa da precipitação e escoamento fluvial na ilha da Madeira. Funchal: LREC.

[81] Vieira, I., Barreto, V., Figueira, C., Lousada, S., \& Prada, S. (2016). The use of detention basins to reduce flash flood hazard in small and steep volcanic watersheds - A simulation from Madeira Island. Journal of Flood Risk Management. doi: $10.1111 /$ jfr3.12285.

[82] Gouveia-Reis, D., Lopes, L., \& Mendonça, S. (2016). A dependence modelling study of extreme rainfall in Madeira Island. Physics and Chemistry of the Earth, 85-93. doi: 10.1016/j.pce.2015.11.006.

[83] Tiago Couto, F., Ducrocq, V., Salgado, R., \& Costa, M. J. (2016). Understanding significant precipitation in Madeira island using high-resolution numerical simulations of real cases. Quarterly Journal of the Royal Meteorological Society. doi: 10.1002/qj.2918.

[84] Calabrò, P. S. (2004). Design storms and water quality control. J. Hydrol. Eng. 9 (1), 28-34.

[85] Müller, T., Schütze, M., Bárdossy, A. (2017). Temporal asymmetry in precipitation time series and its influence on flow simulations in combined sewer systems. Adv. Water Resour. 107, 56-64.

[86] Vaes, G., Willems, P., Berlamont, J. (2001). Rainfall input requirements for hydrological calculations. Urban Water 3 (12), 107-112.

[87] Tehrany MS, Pradhan B, Mansor S, AhmadN (2015). Flood susceptibility assessment using GIS-based support vector machine model with different kernel types. Catena 125: 91101. https://doi.org/10.1016/j.catena.2014.10.017.

[88] Lencastre, A., \& Franco, F. M. (2006). Lições de Hidrologia $3^{a}$ edição revista. Lisboa: Fundação da Faculdade de Ciências e Tecnologia da Universidade Nova de Lisboa.

[89] Orr, T. S, Domaradzki, J. A., Spedding, G. R. \& Constantinescu, G. S. (2015). Numerical simulations of the near wake of a sphere moving in a steady, horizontal motion through a linearly stratified fluid at ReD1000. Phys. Fluids 27 (3), 035113.

[90] Pal, A., Sarkar, S., Posa, A., \& Balaras, E. (2016). Regeneration of turbulent fluctuations in low-Froude-number ow over a sphere at a Reynolds number of 3700 . Cambridge University Press. doi: http://dx.doi.org/10.1017/jfm.2016.526.

[91] ASCE Task Force Committee of the Hydraulic Division. (1963) Friction Factors in Open Channels, Progress Report of the Task Force on Friction factors in Open Channels of the Committee of the Hydraulic Division. J. of Hydr. Div. 89 (HY2).

[92] Kazemipour, A. K., Apelt, C. J. (1980). Resistance to Flow in irregular Channels Dept. of Civil Eng., Research Report Series No. CE7, University of Queensland, Australia.

[93] Keulegan, G. H. (1938). Laws of Turbulent Flow in Open Channels. Journal of Research of the National Bureau of Standards. Research Paper 1151, 21, 707-741.

[94] Nikuradse, J. (1933). Stromungsgesetze in rauhen Rohre (Low of flow in rough pipes). Forschungsheft No. 361, Verein Deutscher Inginieure, Berlin. (Translated into English as NACA TM 1292, Nov. 1950).

[95] Pillai, N. N. (1970). On uniform flow through smooth rectangular open channels. Journal of Hydraulic Research. 8 (4), 403-418.

[96] Yen, B. C. (ed.) (1992). Channel flow resistance: centennial of Manning's formula. Water Resources Publication, Colorado, USA, 1-136.

[97] Chang, S. (2016). Research on scouring and deposition features and impact factors of gully debris flow-a case study on Jiangjia Gully, Yunnan Province, Thesis PhD, Institute of Mountain Hazards and Environment, Chinese Academy of Sciences, Chengdu.

[98] He, S., Wang, D., Chang, S., Fang, Y., Lan, H. (2018). Effects of the morphology of sediment-transporting channels on the erosion and deposition of debris flows. Environmental Earth Sciences. doi: https://doi.org/10.1007/s12665-018-7721-y.

[99] Hossain, A., Jia, Y., \& Chao, X. (2009). Estimation of Manning's roughness coefficient distribution for hydrodynamic model using remotely sensed land cover features. 17th International Conference on Geoinformatics, Geoinformatics 2009 (pp. 1-4). Fairfax, Virginia, USA: George Mason University. doi: 10.1109/GEOINFORMATICS.2009.5293484.

[100] Mata-Lima, H., Raminhos, C., \& Silva, V. V. (2008). Controlo do Escoamento e Medição de Caudais: critérios de dimensionamento de descarregadores em canais, colectores e pequenas represas. Revista de Engenharia Civi, Universidade do Minho, 51-66. Retrieved from https://www.researchgate.net/publication/237479081.

[101] Ricardo, A. M., Franca, M. J., \& Ferreira, R. M. (2010). Caracterização do escoamento turbulento em canais com vegetação emersa rígida. $10^{\circ}$ Congresso da Água, APRH (pp. 55-68). Portimão, Portugal: APRH. Retrieved from https://www.researchgate.net/publication/277658037.

[102] Aupoix, B. (2015). Revisiting the Discrete Element Method for Predictions of Flows Over Rough Surfaces. Journal of Fluids Engineering. doi: 10.1115/1.4031558.

[103] Dimitriadis, P., Tegos, A., Oikonomou, A., Pagana, V., Koukouvinos, A., Mamassis, N., Efstratiadis, A. (2016). Comparative evaluation of $1 \mathrm{D}$ and quasi-2D hydraulic models based on benchmark and real-world applications for uncertainty assessment in flood mapping. Journal of Hydrology, 478-492. doi: 10.1016/j.jhydrol.2016.01.020.

[104] Hernandez-Duenas, G., \& Beljadid, A. (2016). A centralupwind scheme with natural viscosity for shallow-water flows in channels. Advances in Water Resources, 323-338. doi: 10.1016/J.ADVWATRES.2016.07.021. 
[105] Kitsikoudis, V., Yagci, O., Kirca, V. S., \& Kellecioglu, D. (2016). Experimental investigation of channel flow through idealized isolated tree-like vegetation. Environmental Fluid Mechanics, 1283-1308. doi: 10.1007/s10652-016-9487-7.

[106] Liu, Y., Engel, B. A., Collingsworth, P. D., \& Pijanowski, B. C. (2017). Optimal implementation of green infrastructure practices to minimize influences of land use change and climate change on hydrology and water quality: Case study in Spy Run Creek watershed, Indiana. Science of the Total Environment, 1400-1411. doi: 10.1016/J.SCITOTENV.2017.06.015.

[107] Acevedo-Espinoza, S. (2014). Debt, Growth and Natural Disasters A Caribbean Trilogy. IMF Working Papers. doi: 10.5089/9781498337601.001.

[108] Faccini, F., Luino, F., Sacchini, A., \& Laura, T. (2014). Flash Flood Events and Urban Development in Genoa (Italy): Lost in Translation. XII Congress "Engineering Geology for Society and Territory". Turin: Springer International Publishing Switzerland. doi: 10.1007/978-3-319-09048-1_155.

[109] Fadigas, L. (2015). Urbanismo e território: as politicas públicas. Edições Sílabo.

[110] Neal, J. C., Odoni, N. A., Trigg, M. A., Freer, J. E., Garcia-
Pintado, J., Mason, D. C., Bates, P. D. (2015). Efficient incorporation of channel cross-section geometry uncertainty into regional and global scale flood inundation models. $\begin{array}{llll}\text { Journal of Hydrology, 169-183. doi: } & \end{array}$ 10.1016/j.jhydrol.2015.07.026.

[111] Castanho, R., Loures, L., Fernández, J., and Fernández-Pozo, L., (2016). Identifying critical factors for success in Cross Border Cooperation (CBC) development projects. Habitat International.

[112] Castanho, R., Loures, L., Cabezas, J., \& Fernández-Pozo, L. (2017). Cross-Border Cooperation (CBC) in Southern Europe-An Iberian Case Study. The Eurocity Elvas-Badajoz. Sustainability, 9 (3), 360.

[113] Martínez, F. L., Morales, A. P., \& Guirado, S. G. (2016). In landscape management all of us have something to say. A holistic method for landscape Preservability evaluation in a Mediterranean region. Land Use Policy, 172-183. doi: 10.1016/J.LANDUSEPOL.2015.11.004.

[114] Masum, K. M., Mansor, A., Sah, S. A., \& Lim, H. S. (2017). Effect of differential forest management on land-use change (LUC) in a tropical hill forest of Malaysia. Journal of Environmental Management, 468-474. doi: 10.1016/J.JENVMAN.2017.06.009. 